\title{
TINGKAT KECEMASAN BERHUBUNGAN DENGAN KUALITAS TIDUR IBU HAMIL TRIMESTER III
}

\author{
Eline Charla Sabatina Bingan ${ }^{\bowtie}$ \\ Jurusan Kebidanan Poltekkes Kemenkes Palangka Raya
}

\section{ARTICLE INFO \\ Article history}

Submitted : 2021-07-15

Revised : 2021-08-10

Accepted : 2021-08-17

\section{Keywords: \\ Anxiety level \\ Pregnant women \\ Sleep quality \\ Third Trimester}

\section{$\triangle$ Corresponding Author:}

Tingkat kecemasan Kualitas tidur

Ibu hamil

Trimester III

\begin{abstract}
Pregnancy is a biological and psychological condition which certainly requires adaptation for women who are experiencing it. In the United States there are 40 million people experiencing anxiety disorders before childbirth. Third trimester pregnant women often feel afraid and anxious about the child who will be born later, so that pregnant women experience sleep quality disturbances. The purpose of this study was to determine the relationship between anxiety level and sleep quality of third trimester pregnant women at Ketapang Health Center. This type of quantitative research with a cross sectional approach. The population was 130 respondents in the third trimester of pregnant women at the Ketapang Health Center. The number of samples was 45 respondents using purposive sampling technique. Sleep quality variables used the PSQI (Pittsburgh Sleep Quality Index) questionnaire and the anxiety level variables used the HARS (Hamilton Rating Scale For Anxiety) questionnaire with data analysis tests using the Spearman Rho correlation test with a 95\% confidence level. The results of the bivariate analysis showed that respondents who experienced mild anxiety with good sleep quality were 3 people $(60 \%)$ and respondents who experienced severe anxiety with poor sleep quality were 15 people (83.3\%). The correlation test between Anxiety Level and Sleep Quality for Third Trimester Pregnant Women obtained $p$ value $=0.000$, so it can be concluded that there is a relationship between anxiety levels and sleep quality for third trimester pregnant women at the Ketapang Health Center. Future research is expected to use other factors that can affect the quality of sleep of pregnant women, especially in the third trimester of pregnancy.

Kehamilan merupakan kondisi biologis maupun psikis yang tentunya memerlukan adaptasi bagi wanita yang sedang mengalaminya, di Amerika Serikat terdapat 40 juta orang mengalami gangguan kecemasan menjelang persalinan. Ibu hamil trimester III sering merasa takut dan cemas terhadap anak yang akan dilahirkan nanti, sehingga ibu hamil mengalami gangguan kualitas tidur. Tujuan penelitian ini untuk mengetahui hubungan tingkat kecemasan dengan kualitas tidur ibu hamil trimester III di Puskesmas Ketapang. Jenis penelitian kuantitatif dengan pendekatan cross sectional. Populasi sebanyak 130 reponden ibu hamil trimester III di Puskesmas Ketapang. Jumlah sampel 45 reponden dengan teknik pengambilan sampel Purposive Sampling. Variabel kualitas tidur menggunakan kuesioner PSQI (Pittsburgh Sleep Quality Index) dan variabel tingkat kecemasan menggunakan kuesioner HARS (Hamilton Rating Scale For Anxiety) dengan uji analisis menggunakan uji korelasi Spearman Rho dengan tingkat kepercayaan $95 \%$. Hasil analisis bivariat menunjukan bahwa reponden yang mengalami kecemasan ringan dengan kualitas tidur baik sebanyak 3 orang $(60 \%)$ dan responden yang mengalami kecemasan berat dengan kualitas tidur buruk sebanyak 15 orang (83,3\%). Uji Hubungan Tingkat Kecemasan dengan Kualitas Tidur Ibu Hamil Trimester III diperoleh nilai $\mathrm{p}=0,000$, maka dapat disimpulkan ada hubungan tingkat kecemasan dengan kualitas tidur ibu hamil trimester III di Puskesmas Ketapang. Penelitian selanjutnya diharapkan menggunakan faktor lain yang dapat mempengaruhi kualitas tidur ibu hamil terutama di kehamilan trimester III.
\end{abstract}

Eline Charla Sabatina Bingan

Jurusan Kebidanan Poltekkes Kemenkes Palangka Raya

Telp. 085249210188

Email: elincharlabingan@gmail.com

\section{PENDAHULUAN}

Kehamilan merupakan sesuatu yang wajar terjadi pada wanita yang produktif. Pada setiap masa kehamilan ibu akan mengalami beberapa perubahan, baik perubahan fisik maupun perubahan psikologis yang cukup 
spesifik sebagai reaksi dari apa yang dirasakan pada masa kehamilan.

Pada trimester III, perubahan psikologi ibu terkesan lebih kompleks dan meningkat kembali dibanding trimester sebelumnya, dan ini tidak lain dikarenakan kondisi kehamilan yang semakin membesar dan akan dilakukannya persalinan dan memikirkan tugastugas apa yang akan dilakukan setelah kelahiran (Janiwarty \& Pieter, 2013). Pada trimester III wanita hamil mengalami kecemasan semakin bertambah yang disebabkan karena munculnya rasa takut untuk melahirkan dan kekhawatiran semakin membesar terhadap anak yang akan dilahirkan nanti (Detiana, 2013). Tingkat kecemasan ibu akan semakin meningkat. Banyak calon ibu sering berkhayal atau bermimpi tentang hal-hal negatif akan terjadi pada bayinya saat melahirkan nanti.

Ada beberapa permasalahan yang muncul pada kehamilan trimester III antara lain nyeri punggung bawah karena meningkatnya beban berat ibu, jumlah jam tidur menurun karena ibu sulit untuk tidur (insomnia), lebih sedikit waktu untuk tidur nyenyak, lebih sering terbangun di malam hari, sulit menemukan posisi yang nyaman, sering buang air kecil. Hal ini sejalan dengan penelitian (Mediarti et al., 2014) yang menjelaskan bahwa keluhan yang dirasakan ibu hamil trimester III diantaranya posisi tidur yang tidak nyaman dan sulit tidur.

Menurut data hasil survei National sleep Foundation (2016), 78\% wanita hamil di Amerika mengalami gangguan tidur dan 97,3\% dan wanita hamil trimester III selalu terbangun dimalam hari. Rata-rata $3-11$ kali setiap malam. Gangguan tidur ini meningkatkan risiko meningginya tekanan darah saat hamil menjadi empat kali lipat. Studi yang dilakukan University of Pittsburgh School of Medicine menunjukkan kualitas dan kuantitas tidur yang buruk akan mengganggu proses kekebalan tubuh. Pada ibu hamil, hal itu akan memperbesar risiko berat bayi lahir rendah, preeklamsi dan komplikasi kesehatan lain.

Berdasarkan kasus kematian Ibu yang ada di Kabupaten Barito Utara tahun $2010-$ 2014 sebanyak 346 kasus, tahun 2015 - 2018 sebanyak 305 kasus dan pada tahun 2019 sampai sekarang sebanyak 306 kasus, dimana penyebab kasus kematian ibu pada tahun 2016 - 2019 disebabkan oleh hipertensi 33,07\% pendarahan $27,03 \%$ dan infeksi kehamilan
6,06\% (Dinas Kesehatan Kabupaten Barito Utara, 2020).

Berdasarkan hasil wawancara yang dilakukan kepada 10 orang ibu hamil trimester III, 10 orang ibu hamil mengatakan sulit tidur karena mengkhawatirkan nasib janin yang sedang dia kandung, mereka mengeluhkan cemas dan takut pada saat memasuki trimester III jika nanti anaknya dilahirkan tidak normal. Berdasarkan wawancara Ibu hamil trimester III 10 orang menyatakan frekuensi tidur $3-4$ jam sehari karena nyeri punggung bawah dan meningkatnya beban berat ibu, jumlah jam tidur menurun karena ibu sulit untuk tidur (insomnia), lebih sedikit waktu untuk tidur nyanyak, lebih sering terbangun dimalam hari, sulit menemukan posisi yang nyaman, sering buang air kecil. Berdasarkan latar belakang di atas peneliti tertarik untuk melakukan penelitian tentang hubungan tingkat kecemasan dengan kualitas tidur pada ibu hamil trimester III di Wilayah Wilayah Puskesmas Ketapang Kecamatan Gunung Timang Kabupaten Barito Utara.

\section{METODE PENELITIAN \\ Jenis Penelitian}

Jenis penelitian ini menggunakan observasional analitik dengan pendekatan Cross Sectional Study.

\section{Lokasi dan Waktu Penelitian}

Penelitian ini dilaksanakan di Wilayah Puskesmas Ketapang Kecamatan Gunung Timang Kabupaten Barito Utara selama 4 minggu yaitu pada 17 Maret - 17 April 2021.

\section{Populasi dan Sampel}

Populasi dalam penelitian ini adalah semua klien ibu hamil Trimester III di Wilayah Puskesmas Ketapang Kecamatan Gunung Timang Kabupaten Barito Utara sebanyak 130 orang pada bulan Januari - Agustus 2020. Pengambilan sampel menggunakan teknik purposive sampling dengan kriteria inklusi dan eksklusi didapatkan jumlah sampel 45 responden.

\section{Pengumpulan Data}

Peneliti membagikan kuesioner mengenai tingkat kecemasan dan kualitas tidur pada Ibu Hamil Trimester III. Peneliti melakukan penelitian yang sesuai dengan prinsip-prinsip 
etis penelitian yaitu meminta persetujuan kepada responden.

\section{Pengolahan dan Analisis Data}

Setelah data terkumpul, peneliti melakukan tahap pengolahan dan analisis data dengan menggunakan komputer program SPSS. Proses yang dilakukan dimulai dengan tahapan editing, coding, entry data, cleaning data, dan penyajian data dalam bentuk tabel distribusi frekuensi.

\section{HASIL PENELITIAN}

Berdasarkan tabel 1 dapat diketahui dari 45 ibu hamil trimester III di Wilayah Pukesmas Ketapang Kabupaten Barito Utara, yang berpartisipasi dalam penelitian ini sebanyak $75.6 \%$ ibu hamil berusia $19-29$ tahun. Sedangkan sebanyak $24.4 \%$ ibu hamil berusia $30-40$ tahun. Dapat disimpulkan bahwasanya ibu hamil trimester III di Wilayah Pukesmas Ketapang Kabupaten Barito Utara, yang berpartisipasi dalam penelitian ini paling banyak berusia $19-29$ tahun.

Tabel 1. Distribusi Frekuensi Responden Berdasarkan Umur, Pendidikan, dan Pekerjaan

\begin{tabular}{lcc}
\hline Variabel & Frekuensi (n) & Persentase (\%) \\
\hline Umur (Tahun) & & \\
$19-29$ & 34 & 75,6 \\
$30-40$ & 11 & 24,4 \\
\hline Jumlah & 45 & 100 \\
\hline Pendidikan & & \\
Dasar & 10 & 22.2 \\
Menengah & 27 & 60 \\
Tinggi & 8 & 17.8 \\
\hline Jumlah & 45 & 100 \\
\hline Pekerjaan & & \\
Bekerja & 21 & 46.7 \\
Tidak bekerja & 24 & 53.3 \\
\hline Jumlah & 45 & 100 \\
\hline
\end{tabular}

Dari 45 ibu hamil trimester III di Wilayah Pukesmas Ketapang Kabupaten Barito Utara, yang berpartisipasi dalam penelitian ini sebanyak $22.2 \%$ ibu hamil memiliki pendidikan terakhir tingkat dasar. Sedangkan sebanyak $60.0 \%$ ibu hamil memiliki pendidikan terakhir tingkat menengah dan sebanyak $17.8 \%$ ibu hamil memiliki pendidikan terakhir tingkat Tinggi. Dapat disimpulkan bahwasanya ibu hamil trimester III di Wilayah Puskesmas
Ketapang Kabupaten Barito Utara, yang berpartisipasi dalam penelitian ini paling banyak memiliki pendidikan terakhir tingkat menengah.

Dari 45 ibu hamil trisemester III di Wilayah Pukesmas Ketapang Kabupaten Barito Utara, yang berpartisipasi dalam penelitian ini sebanyak $46.7 \%$ ibu hamil menyatakan tidak bekerja dan sebanyak $53.3 \%$ ibu hamil menyatakan bekerja. Dapat disimpulkan bahwasanya ibu hamil trimester III di Wilayah Pukesmas Ketapang Kabupaten Barito Utara, yang berpartisipasi dalam penelitian ini paling banyak ibu hamil menyatakan bekerja.

Tabel 2. Distribusi Frekuensi Variabel Tingkat Kecemasan dan Kualitas Tidur

\begin{tabular}{lcc}
\hline \multicolumn{1}{c}{ Variabel } & $\begin{array}{c}\text { Frekuensi } \\
(\mathbf{n})\end{array}$ & $\begin{array}{c}\text { Persentase } \\
(\boldsymbol{\%})\end{array}$ \\
\hline Tingkat Kecemasan & & \\
Tidak Ada Kecemasan & 10 & 22.2 \\
Kecemasan Ringan & 5 & 11.1 \\
Kecemasan Sedang & 9 & 20.0 \\
Kecemasan Berat & 15 & 33.3 \\
Kecemasan Berat Sekali & 6 & 13.3 \\
\hline Jumlah & 45 & 100.0 \\
\hline Kualitas Tidur & & \\
Kualitas Tidur Baik & 18 & 40.0 \\
Kualitas Tidur Buruk & 27 & 60.0 \\
\hline Jumlah & 45 & 100.0 \\
\hline
\end{tabular}

Berdasarkan tabel 2 dapat diketahui bahwa dari 45 ibu hamil trimester III di Wilayah Pukesmas Ketapang Kabupaten Barito Utara, yang berpartisipasi dalam penelitian ini sebanyak $22.2 \%$ ibu hamil tidak mengalami kecemasan. Kemudian sebanyak $11.1 \%$ ibu hamil mengalami kecemasan ringan. Selanjutnya sebanyak $20.0 \%$ ibu hamil mengalami kecemasan sedang. Berikutnya sebanyak $33.3 \%$ ibu hamil mengalami kecemasan berat. Dan sebanyak $13.3 \%$ ibu hamil mengalami kecemasan berat sekali. Dapat disimpulkan bahwasanya ibu hamil trimester III di Wilayah Pukesmas Ketapang Kabupaten Barito Utara, yang berpartisipasi dalam penelitian ini paling banyak ibu hamil mengalami kecemasan berat.

Dari 45 ibu hamil trimester III di Wilayah Pukesmas Ketapang Kabupaten Barito Utara, yang berpartisipasi dalam penelitian ini sebanyak $40.0 \%$ ibu hamil memiliki kualitas tidur yang baik. Dan sebanyak $60.0 \%$ ibu hamil memiliki kualitas tidur yang buruk. Dapat 
disimpulkan bahwasanya ibu hamil trimester III di Wilayah Pukesmas Ketapang Kabupaten Barito Utara, yang berpartisipasi dalam penelitian ini paling banyak ibu hamil memiliki kualitas tidur yang buruk.

Tabel 3. Hubungan Antara Tingkat Kecemasan dengan Kualitas Tidur pada Ibu Hamil Trimester III di Wilayah Puskesmas Ketapang Kabupaten Barito Utara

\begin{tabular}{ccccccccc}
\hline & \multicolumn{4}{c}{ Kualitas Tidur } & \multicolumn{2}{c}{ Jumlah } & \multirow{2}{*}{ P Value } \\
\cline { 2 - 6 } Tingkat Kecemasan & \multicolumn{3}{c}{ Baik } & \multicolumn{2}{c}{ Buruk } & & \\
\cline { 2 - 7 } & $\mathbf{n}$ & $\mathbf{\%}$ & $\mathbf{n}$ & $\mathbf{\%}$ & $\mathbf{n}$ & $\mathbf{\%}$ & \\
\hline Tidak Ada Kecemasan & 8 & 80 & 2 & 20 & 10 & 100 \\
Kecemasan Ringan & 3 & 60 & 2 & 40 & 5 & 100 & \\
Kecemasan Sedang & 3 & 33.3 & 6 & 66.7 & 9 & 100 & \multirow{2}{*}{0.021} \\
Kecemasan Berat & 3 & 20 & 12 & 80 & 15 & 100 & \\
Kecemasan Berat Sekali & 1 & 16.7 & 5 & 83.3 & 6 & 100 & \\
\hline Total & $\mathbf{1 8}$ & $\mathbf{4 0 . 0 0}$ & $\mathbf{2 7}$ & $\mathbf{6 0 . 0 0}$ & $\mathbf{4 5}$ & $\mathbf{1 0 0}$ & \\
\hline
\end{tabular}

Berdasarkan pada tabel 3 hasil penelitian ini menunjukkan bahwa responden yang mengalami tingkat kecemasan ringan dengan kualitas tidur baik sebanyak 3 orang (60\%). Responden yang mengalami kecemasan berat dengan kualitas tidur buruk sebanyak 12 orang $(80 \%)$ sedangka responden yang mengalami kecemasan berat sekali dengan kualitas tidur buruk sebanyak 5 orang (83.3\%).

\section{PEMBAHASAN}

Hasil penelitian ini didapatkan bahwa ibu hamil trimester III terbanyak berumur 19-29 tahun sebanyak 34 orang $(75,5 \%)$. Hal ini terjadi karena pada usia $19-29$ tahun ibu hamil muda dan kehamilan pertama cenderung menimbulkan kecemasan yang lebih tinggi dari pada ibu hamil cukup usia yang sudah pernah melahirkan. Dalam periode ini, seorang wanita akan menghadapi resiko komplikasi, kehamilan pada usia muda dan kecemasan pada kehamilan pertama dapat menambah tekanan jiwa. Permasalahan medis yang mungkin terjadi adalah anemia, tekanan darah tinggi, persalinan prematur dan bedah cesar saat melahirkan bayinya. Hasil penelitian (Rahmitha, 2017) yaitu kelompok usia muda mengalami cemas berat yaitu $13,5 \%$, umur cukup mengalami cemas ringan yaitu $29,7 \%$ dan usia tua 2,7\% tidak mengalami kecemasan.

Pada penelitian ini menunjukkan bahwa sebagian besar responden berpendidikan menengah (SMA) sebanyak 27 orang (60\%).
Tingkat pendidikan dapat mempengaruhi tingkat pengetahuan responden karena kemampuan seseorang dalam menerima dan memahami ditentukan oleh tingkat pendidikan yang dimiliki. Menurut (Corneles \& Losu, 2015), penerimaan dan pemahaman terhadap informasi yang diterima seorang yang berpendidikan tinggi lebih baik dibandingkan dengan seseorang yang berpendidikan rendah.

Hasil penelitian ini menunjukan bahwa yang berpartisipasi dalam penelitian sebanyak 46.7\% ibu hamil menyatakan tidak bekerja dan sebanyak $53.3 \%$ ibu hamil menyatakan bekerja. Dapat disimpulkan bahwa ibu hamil trimester III di Wilayah Pukesmas Ketapang Kabupaten Barito Utara, yang berpartisipasi dalam penelitian ini paling banyak ibu hamil bekerja. Pekerjaan merupakan salah satu faktor yang mempengaruhi kuantitas tidur. Pekerjaan yang terlalu berat akan menimbulkan kelelahan baik fisik maupun psikis (Wahyuni \& Ni'mah, 2013).

Hasil penelitian menunjukan bahwa ibu hamil trimester III yang tidak mengalami kecemasan sampai dengan kecemasan ringan sebanyak 4 orang $(8,9 \%)$ dan sebagian besar responden mengalami kecemasan berat sebanyak 18 orang (40\%). Penelitian ini sesuai dengan teori yang dikemukakan oleh (Janiwarty \& Pieter, 2013), bahwa pada fase trimester ketiga perubahan-perubahan psikologis pada ibu hamil semakin komplek dan meningkat dari trimester sebelumnya. Hal ini dikarenakan 
kondisi kehamilan yang semakin membesar. Beberapa kondisi psikologis yang terjadi pada trimester III, diantaranya perubahan emosional, rasa tidak nyaman, gangguan tidur. Perubahan emosi ini disebabkan adanya perasaan khawatir, rasa takut, rasa cemas dan ragu dengan kondisi kehamilannya.

Selanjutnya hasil penelitian ini menunjukkan bahwa ibu hamil trimester III sebagian besar responden mengalami kualitas tidur buruk sebanyak 30 orang $(66,7 \%)$. Menurut pendapat peneliti bahwa sebagian besar ibu hamil yang mengalami gangguan tidur dikarenakan merasakan kecemasan akan mengahadapi persalinan, sering terbangun untuk berkemih, kontraksi janin dan sukar untuk bernafas. Pada saat peneliti melakukan penelitian, didapatkan sebagian besar ibu hamil mengatakan bahwa sebelum tidur selalu terbayang-bayang akan persalinan yang akan dihadapinya nanti dan mencemasakan akan nasib anak dan dirinya kelak ketika dilakukan persalinan sehingga ibu hamil sukar untuk memulai masuk tidur. Karena perut ibu yang sudah membesar, ada sebagian ibu hamil mengeluhkan kesukaran untuk menentukan posisi tidur. Melihat dari hasil penelitian yang telah dilakukan menunjukkan bahwa ibu hamil memiliki kualitas tidur yang buruk dipicu oleh adanya peningkatan frekuensi BAK meningkat, kesulitan untuk bernafas, kecemasan menghadapi persalinan, nyeri punggung dan kontraksi janin.

Penelitian ini menunjukkan bahwa responden yang mengalami tingkat kecemasan ringan dengan kualitas tidur baik sebanyak 3 orang $(60 \%)$ dan responden yang mengalami kecemasan berat dengan kualitas tidur buruk sebanyak 12 orang $(80 \%)$. Kecemasan sering kali mengganggu tidur. Seseorang yang pikirannya dipenuhi dengan masalah pribadi dan merasa sulit untuk rileks saat akan memulai tidur. Kecemasan meningkatkan kadar norepinefrin dalam darah melalui stimulasi sistem saraf simpatis. Perubahan kimia ini menyebabkan kurangnya waktu tidur tahap IV NREM dan tidur REM serta lebih banyak perubahan dalam tahap tidur lain dan lebih sering terbangun. Gangguan psikis seperti kecemasan membuat ibu semakin susah untuk tidur, terutama di trimester akhir cemas menghadapi persalinan nantinya, dan apakah bayinya lahir normal atau cacat (Janiwarty \& Pieter, 2013).
Hasil ini sejalan dengan penelitian (Robin, 2015), tentang hubungan tingkat kecemasan dengan kualitas tidur pada ibu hamil primigravida trimester III di Puskesmas Sidorejo Lampung Timur yang menyatakan bahwa sebanyak 7 responden $(63,5 \%)$ tidak mengalami kecemasan sampai kecemasan ringan dengan kuaitas tidur yang baik, sedangkan responden dengan kecemasan sedang sampai kecemasan berat dan memiliki kualitas tidur buruk sebnyak 20 responden (83,3\%). Penelitian Gede Robin sejalan dengan hasil yang dilakukan peneliti ini bahwa kecemasan dapat mempengaruhi kualitas tidur karena ibu hamil sering memikirkan proses persalinan yang semakin dekat.

Kecemasan dapat mempengaruhi kualitas tidur karena ibu hamil sering memikirkan proses persalinan yang semakin dekat. Sehingga hal itu menyebabkan ibu hamil sulit untuk memulai tidur dan sering terbangun di malam hari. Hal ini menunjukkan bahwa semakin tinggi tingkat kecemasan maka akan semakin buruk kualitas tidur yang dimilki ibu hamil. Selain kecemasan menjelang persalinan, seluruh responden menyatakan sering terbangun di malam hari karena sering buang air kecil, nyeri punggung, sulit untuk bernafas (sesak), merasa gerah dan kontraksi janin.

Hal ini menunjukkan bahwa bukan hanya karena kecemasan saja yang mempengaruhi kualitas tidur, namun dipengaruhi juga oleh faktor-faktor fisik ibu hamil itu sendiri. Penelitian ini sejalan dengan penelitian (Komalasari et al., 2012) tentang hubungan tingkat kecemasan dengan kualitas tidur pada Ibu Hamil Multigravida Trimester III di Puskesmas Jatinangor Kabupaten Sumedang, yang menyatakan bahwa responden yang mengalami cemas sebanyak 14 orang $(25,9 \%)$ memiliki tingkat kecemasan sedang dengan kualitas tidur baik.

\section{KESIMPULAN DAN SARAN}

Diketahui bahwa nilai probabilitas $\mathrm{Chi}$ Square sebesar 0.021. Berdasarkan hal ini dapat dinyatakan bahwa terdapat hubungan yang signifikan antara tingkat kecemasan dengan kualitas tidur pada ibu hamil trimester III di Wilayah Kerja Puskesmas Ketapang Kabupaten Barito Utara.

Disarankan kepada pemberi layanan kesehatan agar dapat lebih optimal dalam melakukan asuhan kebidanan mengenai kualitas 
tidur yang buruk serta melakukan penyuluhan yang mendalam tentang pentingnya nutrisi, pengetahuan dan dukungan keluarga. Hal ini untuk memotivasi ibu hamil agar ibu bisa mengatasi kecemasan serta dapat dengan mudah untuk melakukan aktivitas tidur pada malam hari. Untuk penelitian selanjutnya disarankan untuk meneliti tentang gambaran faktor-faktor yang dapat mempengaruhi kualitas tidur pada ibu hamil trimester III. Pada saat melakukan penelitian, bukan hanya faktor kecemasan saja yang peneliti dapatkan mengenai penyebab dari kualitas tidur yang buruk pada ibu hamil trimester III.

\section{DAFTAR PUSTAKA}

Corneles, S. M., \& Losu, F. N. (2015). Hubungan Tingkat Pendidikan dengan Pengetahuan Ibu Hamil Tentang Kehamilan Risiko Tinggi. Jurnal Ilmiah Bidan, 3(2), 51-55.

Detiana, P. (2013). Hamil Aman dan Nyaman di Atas 30 Tahun. Media Pressindo.

Dinas Kesehatan Kabupaten Barito Utara. (2020). Data Jumlah Angka Kematian Ibu.

Janiwarty, B., \& Pieter, H. Z. (2013). Pendidikan Psikologi untuk Bidan: Suatu Teori dan Terapannya (D. Hardjono (ed.)). Rapha Publishing.

Komalasari, D., Maryati, I., \& Koeryaman, M. T. (2012). Hubungan Antara Tingkat
Kecemasan Dengan Kualitas Tidur Pada Ibu Hamil Trimester Iii Di Puskesmas Jatinangor Kabupaten Sumedang. Students E-Journals, 1(1), 1-16.

Mediarti, D., Sulaiman, Rosnani, \& Jawiah. (2014). Pengaruh Yoga Antenatal Terhadap Pengurangan Keluhan Ibu Hamil Trimester III. Jurnal Kedokteran \& Kesehatan. Jurnal Kedokteran Dan Kesehatan, 1(1), 47-53.

Rahmitha, N. (2017). Tingkat Kecemasan pada Ibu Hamil Primigravida Trimester III di Puskesmas Kecamatan Tamalanrea Makassar. Universitas Hasanuddin Makassar.

Robin, G. (2015). Hubungan Tingkat Kecemasan dan Kualitas Tidur pada Ibu Hamil Primigravida Trimester III di Puskesmas Sidorejo Lampung Timur [Universitas Malahayati Bandar Lampung]. https://dokumen. tips/ documents/skripsi-hubungan- tingkatkecemasan-dengan- kualitas-tidur-ibuhamil-primigravida.html.

Wahyuni, \& Ni'mah, L. (2013). Manfaat Senam Hamil untuk Meningkatkan Durasi Tidur Ibu Hamil. Jurnal Kesehatan Masyarakat Andalas, 8(2), 145-152. 